\title{
ALLEVIATION OF CHRONIC HEAT STRESS IN BROILERS BY DIETARY SUPPLEMENTATION OF NOVEL FEED ADDITIVE COMBINATIONS
}

\author{
Saad I. Al-Sultan¹, Sherief M. Abdel-Raheem ${ }^{1,2 *}$, Sherief M.S. Abd-Allah³, \\ Abobakr M. Edris ${ }^{1,4}$
}

${ }^{1}$ Department of Veterinary Public Health and Animal Husbandry, College of Veterinary Medicine, King Faisal University, 400 Al-Ahsa ,31982, Saudi Arabia, ${ }^{2}$ Department of Animal Nutrition and Clinical Nutrition, Faculty of Veterinary Medicine, Assiut University, 71526, Egypt, ${ }^{3}$ Department of Food Hygiene (Meat Hygiene), Faculty of Veterinary Medicine, Assiut University, 71526, Egypt, ${ }^{4}$ Food hygiene and control Department, Faculty of Veterinary Medicine, Benha University, Egypt

*Corresponding author, E-mail: sdiab@kfu.edu.sa

\begin{abstract}
Heat stress causes economic losses via decreasing feed intake, nutrient digestion, weight gain, feed conversion, immunity, carcass quality and increasing mortality in broilers. The aim of the study was to assess the ability of dietary additive combinations to ameliorate the detrimental effect caused by chronic heat stress $\left(32 \pm 2^{\circ} \mathrm{C}\right.$ for $24 \mathrm{~h}$ per d) on performance, carcass traits, metabolic status and economic efficiency of broiler chickens. A total of 420 , one-day old Cobb-500 broiler chicks were assigned into seven treatment groups $(n=60)$ of five replicates. Each replicate contained 12 unsexed chicks. The control groups did not receive any supplementation to the basal diet (thermoneutral control (TNC) and heat stress control (HSC) groups). The other groups received control diet supplemented with $1 \%$ cumin plus $1 \%$ turmeric powders (T1); $1.5 \mathrm{~g} / \mathrm{kg}$ potassium chloride plus $2 \mathrm{~g} / \mathrm{kg}$ sodium bicarbonate (T2); 1000 ppm propolis plus 15000 IU vitamin A (T3); 1200 ppb chromium plus 500 ppm vitamin C (T4) ; 1200 ppm betaine plus 500 ppm vitamin $E$ (T5). The results indicated that at $42 \mathrm{~d}$ of age, all dietary additive combinations improved the growth performance indices, carcass traits, concentrations of serum antioxidant enzyme biomarkers, stress biomarkers and economic efficiency in comparison to HSC group. Based on the obtained results, it could be concluded that dietary supplementation with betaine and vitamin $\mathrm{E}$ followed by chromium and vitamin $\mathrm{C}$ combinations offers a good management practice for alleviating heat stress related depression in the performance of broiler chickens.
\end{abstract}

Key words: heat stress; broilers; vitamin C; betaine; chromium; propolis; turmeric

\section{Introduction}

The most obvious constraint on poultry production in Saudi Arabia, especially during summer months is high temperature with high humidity, which causes severe stress on birds and reduces performance. The continuous challenge for the poultry production in tropical and subtropical region all over the world remains heat stress. Hot environments making several alterations in blood hormones, glucose levels, leukocytes, electrolytes and organ functions (1). 
Heat stress causes economic losses via decreasing feed intake, nutrient digestion, weight gain (WG), egg production, feed conversion (FC), immunity, carcass quality and increasing mortality (2).

Heat stress trigger the hypothalamo-hypophyseal adrenocortical axis to secrete corticosteroids (3). The catabolic effects of higher blood corticosteroids elevate the free radicals through changing oxidative metabolism, producing huge damage of cellular functions and cell membrane, which causing muscle degeneration and growth retardation (3). The greatest part of the energy production is directed to thermoregulation mechanisms, which develop stress-induced immunosuppression. The immune suppressed birds are predisposed to numerous dangerous diseases associated with high mortality rates (4)

Dietary modifications by the use of commercial feed additives are considered the most favored and practical ways to mitigate the effect of heat stress in poultry (5). Therefore, dietary inclusion of some selected feed additives could also be effective for the preservation of growth and immunity for broilers during periods of heat stress. Many previous studies illustrated the beneficial effect different dietary supplements on the performance of broilers under heat stress independently $(6,7,8,9,10,11,12)$. These studies revealed that Vitamin A, E, C, play important roles in the performance and immune function of poultry under heat stress. Betaine is a methyl donor and it has methionine sparing effect, help in maintaining cellular water balance, protect the integrity of cell membrane and improve broiler performance and to overcome stress. In addition, the supplementation of dietary electrolytes increase tolerance to heat stress improve performance of broilers under heat stress. Electrolyte prevent acid base balance disturbances and decrease the occurrence of respiratory alkalosis during heat stress. Herbal additive like cumin, turmeric and propolis very rich in flavonoid and aromatic acids and they have antioxidant, anti-inflammatory, antibacterial, antifungal activity and have a positive effect on broiler performance under heat stress. However, few studies have been conducted to detect the best combination at the recommended concentrations suggested by previous studies to mitigate the decline in performance caused by heat stress in broiler chickens. Therefore, the aim of the current study was to detect the best commercial additive combinations to ameliorate the detrimental effect caused by chronic heat stress on performance, carcass traits, metabolic status, antioxidant capabilities and economic efficiency of broiler chickens.

\section{Material and methods}

\section{Experimental animals and protocol}

The current experiment was accomplished according to King Faisal University Animal Care and Use Committee and the experimental protocol was approved by the Deanship for Scientific Research with reference number (Decision No: KFU-REC/2017-04-01).

The experiment was carried out on 420 oneday-old broiler chickens (Cobb - 500) purchased from a marketable hatchery (Al-Ahsa, KSA). Birds were housed in pens with wood shavings floor with 10 birds/m2at the Research and Agriculture Station, King Faisl University, Al-Ahsa, Saudi Arabia from 1 to 42 d old. Water and feed provided ad libitum during 24 hours. Constant observation for health status and behavior usually carried out for broiler chickens. The temperature was kept at $32 \pm 2$ ${ }^{\circ} \mathrm{C}$ with $65 \%$ relative humidity (RH) for $24 \mathrm{~h}$ for all treatment groups except thermoneutral control (TNC). For maintaining the desired temperature and relative air humidity air conditioners, heaters with thermostats, and air circulators were applied. The thermoneutral control group (TNC) were held at thermoneutral chamber with normal ambient temperature $(22 \pm 4$ ${ }^{\circ} \mathrm{C}$ ) and relative humidity $(\mathrm{RH})$ of commercial management program $(55 \pm 3 \%, \mathrm{RH})$ at the same experimental place.

\section{The experimental design}

A total of 420 one-day-old unsexed broiler chickens (Cobb - 500) randomly allocated to 7 experimental groups (60 chick/each). Each group consisted of 5 replicate pens with 12 
chicks each. The control groups did not receive any supplementation to the basal diet (thermoneutral control (TNC) and heat stress control (HSC) groups). The other groups received control diet supplemented with $1 \%$ cumin plus 1 $\%$ turmeric powders (T1); $1.5 \mathrm{~g} / \mathrm{kg}$ potassium chloride plus $2 \mathrm{~g} / \mathrm{kg}$ sodium bicarbonate (T2); $1000 \mathrm{ppm}$ propolis plus $15000 \mathrm{IU}$ vitamin A (T3); $1200 \mathrm{ppb}$ chromium (Cr) plus 500 ppm vitamin $\mathrm{C}(\mathrm{T} 4) ; 1200$ ppm betaine (Bet) plus $500 \mathrm{ppm}$ vitamin E (VE) (T5). According to NRC (13) guidelines, fourteen experimental diets, seven in each feeding phase (starting and growing) were formulated. The basal diets contained $23 \%$ and $20 \%$ protein and $3200 \mathrm{kcal}$ of $\mathrm{ME} / \mathrm{kg}$ for starter and grower diets, respectively. Composition and chemical analysis of broiler basal diets are presented in (Table 1). Proximate composition of feed ingredients were performed according to AOAC (14) and the experimental diets were formulated based on these values. The selected feed additives were thoroughly mixed with small amount of feed on the expense of corn, then homogenized with the total amounts and added to the diet. Prophylactic vaccination against viral diseases was carried out. All chicks were immunized with eye drops by weak Newcastle virus vaccine at age of 7 days and with a live attenuated freeze-dried vaccine (Nobilis ${ }^{\circledR} \mathrm{Ma} 5+$ Clone 30 ) at the age of 20 days.

\section{Broiler performance}

Feed consumption and body weight for each pen were recorded weekly during the whole experiment. Average daily gain, feed intake and feed conversion ratio were calculated during starter ( 1 to $21 \mathrm{~d}$ ), grower ( 22 to $42 \mathrm{~d}$ ), and overall ( 1 to $42 \mathrm{~d}$ ) phases.

\section{Blood Sampling}

Ten birds from each group were used for collection of blood samples at days 21 and 42.The samples were collected into two tubes, one contained EDTA (as anticoagulant) and the other had no anticoagulant. Samples were centrifuged at $3500 \mathrm{~g}$ for $15 \mathrm{~min}$ for gathering plasma and serum, respectively.
Determination of New castle serum antibody titre

The $\log 10$ of serum antibody titer of new castle disease was determined by using commercial ELISA kits (IDEXX ${ }^{\circledR}$ Laboratories, B.V., Netherlands) according to the recommendation of the supplier.

\section{Determination of blood antioxidant enzymes and oxidative stress biomarkers}

The activities of antioxidant biomarkers (glutathione peroxidase (GSHPx), superoxide dismutase (SOD) and malondialdehyde (MDA) were analyzed by spectro-photometrical method with commercial kits obtained from Nanjing Jiancheng Bioengineering Institute (Nanjing, China). All procedures were achieved according to manufacturer's instructions. Plasma corticosterone (CS) levels was assayed by the use of ELISA kit (DetecteX ${ }^{\circledR}$ Corticosterone, EIA kit, Arbor Assays ${ }^{\circledR}$, USA), according to procedures of Quintero-Filho et al. (3).

\section{Determination of blood biochemical profile}

Serum glucose, total protein, albumin, total cholesterol and globulin levels were analyzed spectrophotometrically by using commercial kits from Spinreact company ${ }^{\circledR}$ (Spain) and according to manufacturer's instructions.

\section{Heterophil/lymphocyte $(H / L)$ ratio}

At the end of the experiment $\mathrm{d} 42,10$ birds from each group were used for determination of H/L ratio. Smears were prepared using the standard two-slide wedge procedure for differential leukocyte counts. Subsequently, blood films were air dried and stained with WrightGiemsa Quick stain. The H/L ratio was calculated according to method adopted from (15)

Carcass characteristics and relative organ weight

At 42 day of age, 10 bird from each treatment ( 2 from each pen) were randomly selected and humanely slaughtered according to Islamic method for carcass traits characteristics. The gizzard, bursa of Fabricius, liver, spleen, ab- 
dominal fat, heart, thymus, pancreas, and stomach were removed and blot dry weighed. Relative organ weight was calculated as a percentage of body weight.

\section{Economic efficiency}

Economic efficiency was estimated according to Wealleans et al., (16). Economic efficiency $(\mathrm{EE})=($ Net revenue $/$ total costs $) \times 100$. Relative economic efficiency $(\mathrm{REE})=$ Economic efficiency/economic efficiency of the positive control (17)

\section{Statistical analysis}

Data analysis was accomplished by one-way ANOVA using the procedure of SPSS software version 19 (18). Data were tested for normality before analysis by the use of the KolmogorovSmirnov test. Duncan is multiple range test (19) was used to detect the differences among means and significance level was set at $\mathrm{P}<0.05$.

\section{Results}

The effect of diet supplementation with novel feed additives on growth performance of 42-day broilers was presented in (Table 2). The results presented in (Table 2) indicated the presence of statistically significant differences $(\mathrm{P}<0.05)$ in the broiler growth performance indices such as body weight, feed intake, body weight gain and feed conversion ratio between the different treatment groups because of the dietary inclusion of all supplements. All dietary additive combinations induced a significant improvement in body weight gain, feed intake, feed conversion rate in birds of treatment groups during the entire period of the study ( $d$ $0-42$ ). On the other side, chronic heat stress (HSC group) induced a significant reduction in body weight, weight gain, feed intake, feed conversion efficiency and mortality during the entire period of the study. It is interesting to note that, dietary supplementation with the combination of $1200 \mathrm{ppm}$ betaine and $500 \mathrm{ppm}$ vitamin E followed by $1200 \mathrm{ppb}$ chromium and 500 ppm vitamin $C$ showed the most favorable and the best results regarding all growth performance indices of broilers subjected to heat stress in comparison with other treatment groups.
All the dietary supplements significantly increased $(\mathrm{P}<0.05)$ the carcass weight, dressing weight, dressing percentage or carcass yield and relative liver, heart, gizzard weights in comparison with the HSC group (Table 3). The greater relative organ weights were recorded in $\mathrm{T} 5, \mathrm{~T} 4, \mathrm{~T} 3$ when compared with $\mathrm{T} 1$ and $\mathrm{T} 2$. The major impact of the heat stress on the carcass traits was showed in the increase of the relative abdominal fat in the HSC to about $1.98 \%$, which decreased to 1.03 and $1.12 \%$ in birds receiving both the combination of betaine and vitamin $\mathrm{E}$ and the chromium and vitamin $\mathrm{C}$, respectively. The highest dressing percentage value $(70.27 \%)$ was observed in birds of T5 group in comparison with other treatments groups. The lowest dressing percentage was recorded in the heat stressed control group $(68.42 \%)$. The greater response of the dietary supplements on carcass traits of broilers under chronic heat stress was obtained by dietary supplementation of betaine and vitamin E combination.

Heat stressed broilers had higher $(\mathrm{P}<0.05)$ levels of blood glucose, total cholesterol and albumen and lower $(\mathrm{P}<0.05)$ level of total protein and globulin when compared with all treated groups and TNC (Table 4). The blood levels of triglycerides and total cholesterol were significantly reduced ( $\mathrm{p}<0.01)$ in all treated groups in comparison with heat stressed control (HSC).

In comparison with the heat stressed control, the dietary inclusion of all supplement combinations in broiler diets significantly increased $(P<0.001)$ the activities of antioxidant enzymes (SOD, GSH-Px, ) and TAOC but reduced $(P<0.001)$ the MDA content in the serum of chicks at the ages $42 \mathrm{~d}$ (Table 4$)$. Heat stress reduce blood antioxidant status in broilers and increased the oxidative stress indicators. It was noted that dietary supplementation with selected additive combinations had decreased the concentrations of both $\mathrm{H}$ : $\mathrm{L}$ ratio and corticosterone significantly $(\mathrm{P}<0.001)$ of broilers under heat stress (Table 4) in comparison with HSC group. The concentrations of ND antibodies titer increased significantly $(\mathrm{P}<0.001)$ at 21 and $42 \mathrm{~d}$ of age by dietary additives in treatment groups in comparison with heat stressed 
control and the highest values were noticed in birds of T5, T4 and T3 groups, respectively. This research extends our knowledge that dietary supplementation of betaine and vitamin $\mathrm{E}$, chromium and vitamin $\mathrm{C}$, propolis and vitamin A combinations are better option for enhancing serum antioxidant status and immune response (ND antibodies titer) for broilers exposed to chronic heat stress.

The economic efficiency of 6 weeks old broiler chicks fed diet fortified with different supplement combinations under heat stress are shown on (Table 5). The dietary additive supplementation increased $(\mathrm{P}<0.001)$ the net return and economic efficiency in all treated groups in comparison with HSC group. Concerning the economic feed efficiency and the relative economic efficiency, the highest values were recorded for the treatment groups (T5, T4, T3 and T2) in comparison with T1 and HSC groups.

Table 1: Ingredients and analyzed chemical composition of basal diets

\begin{tabular}{lcc}
\hline Item* (\% unless noted) & Starter diet & Grower and finisher diet \\
\hline Ingredient, $\%$ & 54.64 & 62.55 \\
Corn & 4.11 & 3 \\
Corn gluten meal (60\%) & 32.5 & 26.4 \\
Soybean meal, 44\% & 4.4 & 3.7 \\
Sunflower oil & 1.5 & 1.5 \\
Limestone & 1.8 & 1.8 \\
Dicalcium phosphate & 0.4 & 0.4 \\
Salt & 0.3 & 0.3 \\
Vitamin - mineral premix & 0.2 & 0.2 \\
DL-methionine & 0.1 & 0.1 \\
L- lysine & 0.05 & 0.05 \\
Antioxidant & 100 & 100 \\
Total & & \\
\hline Chemical analysis & 90.11 & 89.94 \\
Dry matter & 23.01 & 20.05 \\
Crude protein & 3200 & 3200 \\
ME(Kcal/kg diet) ${ }^{\mathrm{b}}$ & 1.08 & 1.06 \\
Calcium & 0.45 & 0.43 \\
Non-phytae phosphorus & 0.20 & 0.17 \\
Na & 1.25 & 1.07 \\
Lysine & 0.58 & 0.53 \\
DL-Methionine & 1.05 & 0.87 \\
Methionine+cystine & 2.96 & 2.95 \\
Crude fiber & 6.38 & 6.04 \\
Crude fat & & \\
\hline
\end{tabular}

*Ingredient and nutrient composition are reported on as-fed basis.

a The vitamin and mineral premix provided per $\mathrm{kg}$ of diet: vitamin A, $4000000 \mathrm{IU}$; vitamin D3, $667000 \mathrm{IU}$; vitamin E $3334 \mathrm{mg}$; vitamin K3, $1167 \mathrm{mg}$; vitamin B1, $334 \mathrm{mg}$; vitamin B2, $1667 \mathrm{mg}$; vitamin B3, 3334 mg; B6, 500 mg; vitamin B12 33.4 mg, Folic acid, 334 mg; Biotin, 17 mg; Iron, 10 ; Copper, 2.167; Zinc, 18.334; Manganese 20.0; Iodine, 0.167; Cobalt, 0.034 and Selenium, 0.034.

${ }^{\mathrm{b}}$ ME Calculated based on NRC (1994) feed composition tables 
Table 2: Effect of dietary treatments on body weight (BW), feed intake (FI) and feed conversion ratio (FCR) of boilers under thermoneutral (TN) and heat stress (Mean \pm Pooled SE)

\begin{tabular}{|c|c|c|c|c|c|c|c|c|c|}
\hline Item & TNC & HSC & T1 & T2 & T3 & T4 & T5 & SEM & $\mathbf{P}$ \\
\hline Initial BW (day1) & 40.56 & 41.23 & 40.86 & 41.25 & 42.07 & 41.33 & 40.07 & 0.23 & 0.332 \\
\hline \multicolumn{10}{|l|}{0 to 21 day } \\
\hline BW (day $21 \mathrm{~W} 3$ ) & $904.19^{\mathrm{a}}$ & $417.82^{\mathrm{d}}$ & $621.73^{b}$ & $608.06^{\mathrm{b}}$ & $599.33^{b}$ & $572.40^{\mathrm{c}}$ & $625.31^{\mathrm{b}}$ & 13.39 & $<0.001$ \\
\hline Feed intake $(\mathrm{g} / \mathrm{bird})$ & $1191.04^{\mathrm{a}}$ & $866.2^{\mathrm{e}}$ & $1077.37^{\mathrm{b}}$ & $1013.98^{\mathrm{cd}}$ & $1027.17^{c}$ & $1001.76^{\mathrm{d}}$ & $1019.69^{\mathrm{cd}}$ & 9.05 & $<0.001$ \\
\hline BW gain (g/bird) & $863.62^{\mathrm{a}}$ & $376.59^{\mathrm{e}}$ & $580.86^{b c}$ & $566.81^{\mathrm{bc}}$ & $557.27^{\mathrm{c}}$ & $531.07^{\mathrm{d}}$ & $585.31^{\mathrm{b}}$ & 13.41 & $<0.001$ \\
\hline FCR $(\mathrm{g} / \mathrm{g})$ & $1.38^{\mathrm{d}}$ & $2.32^{\mathrm{a}}$ & $1.86^{\mathrm{bc}}$ & $1.83^{\mathrm{bc}}$ & $1.84^{\mathrm{bc}}$ & $1.89^{\mathrm{b}}$ & $1.74^{\mathrm{c}}$ & 0.02 & $<0.001$ \\
\hline \multicolumn{10}{|l|}{ 22-42 day } \\
\hline Feed intake (g/bird) & $3475.15^{\mathrm{a}}$ & $2431.59^{c}$ & $2612.92^{\mathrm{b}}$ & $2478.13^{c}$ & $2512.65^{c}$ & $2486.72^{c}$ & $2479.62^{\mathrm{c}}$ & 34.7 & $<0.001$ \\
\hline BW gain (g/bird) & $1740.81^{\mathrm{a}}$ & $1045.52^{\mathrm{d}}$ & $1142.93^{c}$ & $1151.5^{\mathrm{c}}$ & $1169.67^{\mathrm{c}}$ & $1217.33^{b}$ & $1177.81^{\mathrm{c}}$ & 21.07 & $<0.001$ \\
\hline $\mathrm{FCR}(\mathrm{g} / \mathrm{g})$ & $1.99^{\mathrm{d}}$ & $2.33^{\mathrm{a}}$ & $2.29^{\mathrm{a}}$ & $2.16^{\mathrm{b}}$ & $2.15^{\mathrm{b}}$ & $2.05^{\mathrm{cd}}$ & $2.11^{\mathrm{bc}}$ & 0.01 & $<0.001$ \\
\hline \multicolumn{10}{|l|}{ 0-42 day } \\
\hline Final BW (day 42) & $2645.00^{\mathrm{a}}$ & $1463.35^{\mathrm{d}}$ & $1664.66^{\mathrm{c}}$ & $1759.56^{c}$ & $1769.00^{\mathrm{b}}$ & $1789.73^{\mathrm{bc}}$ & $1803.13^{\mathrm{bc}}$ & 21.64 & $<0.001$ \\
\hline Feed intake (g/bird) & $4666.18^{a}$ & $3297.79^{d}$ & $3690.28^{b}$ & $3492.11^{\mathrm{c}}$ & $3539.81^{\mathrm{c}}$ & $3488.49^{c}$ & $3499.31^{\mathrm{c}}$ & 42.27 & $<0.001$ \\
\hline BW gain (g/bird) & $2604.43^{\mathrm{a}}$ & $1422.11^{\mathrm{d}}$ & $1723.8^{\mathrm{c}}$ & $1718.31^{\mathrm{c}}$ & $1726.93^{\mathrm{c}}$ & $1748.4^{\mathrm{bc}}$ & $1763.13^{b}$ & 33.33 & $<0.001$ \\
\hline FCR (g/g) & $1.79^{\mathrm{d}}$ & $2.32^{\mathrm{a}}$ & $2.14^{\mathrm{b}}$ & $2.03^{\mathrm{c}}$ & $2.04^{c}$ & $1.99^{\mathrm{d}}$ & $1.98^{\mathrm{d}}$ & 0.01 & $<0.001$ \\
\hline Mortality, \% & 1.75 & 12.77 & 4.44 & 3.88 & 4.88 & 3.33 & 2.22 & 1.09 & 0.08 \\
\hline
\end{tabular}

$\mathrm{BW}$, body weight, $\mathrm{FCR}$, feed conversation ratio $=$ feed intake/ body weight gain

$\mathrm{a}, \mathrm{b}, \mathrm{c}, \mathrm{d}$, e means with different letters in the same row are significantly different at $\mathrm{P}<0.05$.

TNC, thermoneutral control, HSC, heat stress control; basal diet supplemented with:1 \% Cuminand $1 \%$ turmeric powder (T1) ; $1.5 \mathrm{~g} / \mathrm{kg}$ potassium chloride and $2 \mathrm{~g} / \mathrm{kg}$ sodium bicarbonate (T2) ; $15000 \mathrm{IU}$ vitamin A and $1000 \mathrm{ppm}$ propolis (T3); 500 ppmvitamin C and 1200 ppb chromium (T4); 1200 ppm betaine and 500 ppm Vitamin E (T5).

Table 3: Effect of dietary additives on carcass characteristics and relative weight (\% of live weight) of internal organs of broilers under thermoneutral (TN) and heat stress (Mean \pm Pooled SE)

\begin{tabular}{lccccccccc}
\hline \multicolumn{1}{c}{ Item } & TNC & HSC & T1 & T2 & T3 & T4 & T5 & SEM & P \\
\hline Preslaughter weight & $2665.00^{\mathrm{a}}$ & $1621^{\mathrm{e}}$ & $1722^{\mathrm{d}}$ & $1730^{\mathrm{d}}$ & $1788.00^{\mathrm{b}}$ & $1798.00^{\mathrm{bc}}$ & $1831.2^{\mathrm{b}}$ & 56.21 & $<0.001$ \\
Carcass weight & $1872.6^{\mathrm{a}}$ & $1109^{\mathrm{e}}$ & $1206^{\mathrm{d}}$ & $1210^{\mathrm{d}}$ & $1247^{\mathrm{c}}$ & $1258^{\mathrm{c}}$ & $1287^{\mathrm{b}}$ & 40.29 & $<0.001$ \\
Dressing, \% & $70.28^{\mathrm{a}}$ & $68.42^{\mathrm{c}}$ & $70.08^{\mathrm{ab}}$ & $69.94^{\mathrm{ab}}$ & $69.74^{\mathrm{b}}$ & $69.97^{\mathrm{ab}}$ & $70.27^{\mathrm{a}}$ & 0.33 & $<0.001$ \\
Liver, \% & $2.78^{\mathrm{a}}$ & $2.15^{\mathrm{c}}$ & $2.62^{\mathrm{b}}$ & $2.46^{\mathrm{b}}$ & $2.5^{\mathrm{b}}$ & $2.68^{\mathrm{b}}$ & $2.74^{\mathrm{a}}$ & 0.04 & 0.04 \\
Heart \% & $0.76^{\mathrm{a}}$ & $0.45^{\mathrm{d}}$ & $0.71^{\mathrm{b}}$ & $0.65^{\mathrm{c}}$ & $0.62^{\mathrm{c}}$ & $0.72^{\mathrm{b}}$ & $0.75^{\mathrm{b}}$ & 0.11 & 0.001 \\
Gizzard, \% & $1.73^{\mathrm{a}}$ & $1.35^{\mathrm{c}}$ & $1.54^{\mathrm{b}}$ & $1.52^{\mathrm{b}}$ & $1.55^{\mathrm{b}}$ & $1.58^{\mathrm{b}}$ & $1.61^{\mathrm{b}}$ & 0.02 & 0.01 \\
Abdominal fat, \% & $1.65^{\mathrm{b}}$ & $1.98^{\mathrm{a}}$ & $1.23^{\mathrm{d}}$ & $1.48^{\mathrm{bc}}$ & $1.39^{\mathrm{cd}}$ & $1.12^{\mathrm{d}}$ & $1.03^{\mathrm{e}}$ & 0.05 & $<0.001$
\end{tabular}

TNC, thermoneutral control, HSC, heat stress control; basal diet supplemented with: $1 \%$ Cumin and $1 \%$ turmeric powder (T1); $1.5 \mathrm{~g} / \mathrm{kg}$ potassium chloride and $2 \mathrm{~g} / \mathrm{kg}$ sodium bicarbonate (T2) ; $15000 \mathrm{IU}$ vitamin A and $1000 \mathrm{ppm}$ propolis (T3); $500 \mathrm{ppm}$ vitamin C and $1200 \mathrm{ppb}$ chromium (T4); $1200 \mathrm{ppm}$ betaine and $500 \mathrm{ppm}$ Vitamin E (T5) 
Table4: Effect of dietary additives on blood biochemical profile, oxidative stress biomarkers, and ND antibody titre (Mean \pm Pooled SE)

\begin{tabular}{|c|c|c|c|c|c|c|c|c|c|}
\hline Item & TNC & HSC & T1 & $\mathbf{T 2}$ & T3 & T4 & T5 & SEM & $\mathbf{P}$ \\
\hline Glucose, mg/dl & $221.67^{\mathrm{d}}$ & $281.69^{\mathrm{a}}$ & $240.27^{\mathrm{c}}$ & $251.16^{\mathrm{b}}$ & $230.48^{\mathrm{cd}}$ & $224.61^{\mathrm{d}}$ & $226.81^{\mathrm{d}}$ & 3.533 & $<0.001$ \\
\hline Total cholesterol, mg/dl & $126.83^{\mathrm{e}}$ & $174.92^{\mathrm{a}}$ & $153.08^{b}$ & $146.17^{\mathrm{c}}$ & $138.08^{\mathrm{d}}$ & $135.25^{\mathrm{d}}$ & $121.25^{\mathrm{e}}$ & 2.888 & $<0.001$ \\
\hline Total protein, $\mathrm{g} / \mathrm{dl}$ & $3.79^{\mathrm{a}}$ & $2.79^{\mathrm{e}}$ & $3.24^{\mathrm{cd}}$ & $3.37^{\mathrm{c}}$ & $3.47^{\mathrm{bc}}$ & $3.62^{b}$ & $3.94^{\mathrm{a}}$ & 0.062 & $<0.001$ \\
\hline Albumen, g/dl & $1.84^{\mathrm{a}}$ & $1.86^{\mathrm{a}}$ & $1.72 \mathrm{ab}$ & $1.63^{\mathrm{b}}$ & $1.62^{b}$ & $1.62^{\mathrm{b}}$ & $1.53^{\mathrm{b}}$ & 0.028 & 0.004 \\
\hline Globulin, , g/dl & $1.95^{\mathrm{b}}$ & 0.93 & $1.52^{\mathrm{d}}$ & $1.73^{\mathrm{c}}$ & $1.85^{\mathrm{bc}}$ & $2.00^{\mathrm{b}}$ & $2.41^{\mathrm{a}}$ & 0.075 & $<0.001$ \\
\hline Triglycerides, mg/dl & $99.17^{\mathrm{a}}$ & $94.92^{\mathrm{a}}$ & $86.72^{b}$ & $82.29 \mathrm{bc}$ & $77.02^{\mathrm{d}}$ & $85.96^{\mathrm{b}}$ & $80.86^{\text {bc }}$ & 1.59 & $<0.001$ \\
\hline $\mathrm{SOD}, \mathrm{U} / \mathrm{ml}$ & $152.37^{\mathrm{bc}}$ & $127.80^{d}$ & $152.60^{\mathrm{bc}}$ & $154.4^{\mathrm{abc}}$ & $148.4^{\mathrm{c}}$ & $160.60^{\mathrm{a}}$ & $155.60^{\mathrm{ab}}$ & 1.77 & $<0.001$ \\
\hline GSH-PX, n mol/ml & $11.02^{\mathrm{a}}$ & $5.98^{\mathrm{e}}$ & $7.48^{\mathrm{d}}$ & $8.08^{\mathrm{cd}}$ & $8.62^{\mathrm{c}}$ & $9.52^{b}$ & $8.19^{\mathrm{c}}$ & 0.266 & $<0.001$ \\
\hline $\mathrm{MDA}, \mathrm{nmol} / \mathrm{ml}$ & $6.90^{\mathrm{e}}$ & $11.77^{\mathrm{a}}$ & $9.91^{\mathrm{b}}$ & $9.10^{\mathrm{c}}$ & $7.98^{\mathrm{d}}$ & $7.06^{\mathrm{e}}$ & $8.92^{\mathrm{c}}$ & 0.273 & $<0.001$ \\
\hline TAOC, $\mathrm{U} / \mathrm{ml}$ & $8.02^{\mathrm{e}}$ & $8.42^{\mathrm{e}}$ & $9.64^{\mathrm{d}}$ & $10.32^{c}$ & $10.69^{\mathrm{bc}}$ & $12.05^{\mathrm{a}}$ & $10.85^{\mathrm{b}}$ & 0.233 & $<0.001$ \\
\hline Heterophils & $21.51^{\mathrm{e}}$ & $28.9^{\mathrm{a}}$ & $23.88^{\mathrm{ab}}$ & $24.5^{\mathrm{b}}$ & $22.8^{\text {bcde }}$ & $23.1^{\mathrm{abcd}}$ & $22.02^{\mathrm{de}}$ & 23.75 & $<0.001$ \\
\hline lymphocytes & $77.23^{\mathrm{abc}}$ & $71.34^{\mathrm{d}}$ & $76.30^{\text {cd }}$ & 76.94 abc & $77.56^{a b}$ & $76.60^{\mathrm{bc}}$ & $77.80^{\mathrm{a}}$ & 0.365 & $<0.001$ \\
\hline $\mathrm{H} / \mathrm{L}$ ratio & $0.28^{\mathrm{d}}$ & $0.41^{\mathrm{a}}$ & $0.31^{\mathrm{b}}$ & $0.32^{\mathrm{a}}$ & $0.29^{\mathrm{cd}}$ & $0.30^{\mathrm{bc}}$ & $0.28^{\mathrm{d}}$ & 0.006 & $<0.001$ \\
\hline Corticosterone, $\mathrm{ng} / \mathrm{ml}$ & $10.92^{\mathrm{a}}$ & $10.46^{\mathrm{b}}$ & $9.57^{\mathrm{c}}$ & $9.51^{\mathrm{c}}$ & $9.52^{\mathrm{c}}$ & $9.13^{\mathrm{d}}$ & $9.07^{\mathrm{d}}$ & 0.11 & $<0.001$ \\
\hline \multicolumn{10}{|l|}{ ND titer $(\log 10)$} \\
\hline 21 days & $1.95^{\mathrm{g}}$ & $2.27^{\mathrm{f}}$ & $2.47^{\mathrm{e}}$ & $2.58^{\mathrm{d}}$ & $2.76^{\mathrm{c}}$ & $2.87^{\mathrm{b}}$ & $3.11^{\mathrm{a}}$ & 0.06 & $<0.001$ \\
\hline 42 days & $3.14^{\mathrm{e}}$ & $3.51^{\mathrm{d}}$ & $3.67^{\mathrm{c}}$ & $3.74^{b c}$ & $3.86^{\mathrm{b}}$ & $4.44^{\mathrm{a}}$ & $4.48^{\mathrm{a}}$ & 0.08 & $<0.001$ \\
\hline
\end{tabular}

$\mathrm{a}, \mathrm{b}, \mathrm{c}, \mathrm{d}, \mathrm{e}$ means with different letters in the same row are significantly different at $\mathrm{P}<0.05 . \mathrm{ND}=$ Newcastle disease

GSHPx, glutathione peroxidase; SOD, total superoxide dismutase and; MDA, malondialdehyde; TAOC, total antioxidant capacity, $\mathrm{H} / \mathrm{L}$ heterophile/lymphocyte

TNC, thermoneutral control, HSC, heat stress control; basal diet supplemented with: $1 \%$ Cumin and $1 \%$ turmeric powder (T1); $1.5 \mathrm{~g} / \mathrm{kg}$ potassium chloride and $2 \mathrm{~g} / \mathrm{kg}$ sodium bicarbonate (T2) ; $15000 \mathrm{IU}$ vitamin A and $1000 \mathrm{ppm}$ propolis (T3); $500 \mathrm{ppm}$ vitamin C and $1200 \mathrm{ppb}$ chromium (T4); $1200 \mathrm{ppm}$ betaine and $500 \mathrm{ppm}$ Vitamin E (T5)

Table5: Economic analysis of6-week broilers fed different dietary treatments (Mean \pm Pooled SE)

\begin{tabular}{lccccccccc}
\hline \multicolumn{1}{c}{ Item } & TNC & HSC & T1 & T2 & T3 & T4 & T5 & SEM & P \\
\hline Cumulative feed intake (g/bird) & $4666.18^{\mathrm{a}}$ & $3297.79^{\mathrm{d}}$ & $3690.28^{\mathrm{b}}$ & $3492.11^{\mathrm{c}}$ & $3539.81^{\mathrm{c}}$ & $3488.49^{\mathrm{c}}$ & $3499.31^{\mathrm{c}}$ & 42.27 & $<0.001$ \\
Feed cost / bird (SR) & $5.6^{\mathrm{a}}$ & $3.96^{\mathrm{d}}$ & $4.42^{\mathrm{b}}$ & $4.19^{\mathrm{c}}$ & $4.25^{\mathrm{c}}$ & $4.18^{\mathrm{c}}$ & $4.19^{\mathrm{c}}$ & 0.02 & $<0.001$ \\
Total Cost per bird (SR)* & $8.6^{\mathrm{a}}$ & $6.96^{\mathrm{d}}$ & $7.42^{\mathrm{b}}$ & $7.19^{\mathrm{c}}$ & $7.24^{\mathrm{c}}$ & $7.18^{\mathrm{c}}$ & $7.19^{\mathrm{c}}$ & 0.02 & $<0.001$ \\
Total return (SR/bird) & $31.25^{\mathrm{a}}$ & $17.06^{\mathrm{d}}$ & $20.68^{\mathrm{c}}$ & $20.61^{\mathrm{c}}$ & $20.72^{\mathrm{c}}$ & $20.98^{\mathrm{bc}}$ & $21.16^{\mathrm{b}}$ & 0.4 & $<0.001$ \\
Net profit (SR/bird) & $22.65^{\mathrm{a}}$ & 10.11 & 13.26 & 13.42 & 13.47 & 13.79 & 13.95 & 0.35 & $>0.05$ \\
Economic feed efficiency & $263.47^{\mathrm{a}}$ & $145.32^{\mathrm{e}}$ & $178.45^{\mathrm{d}}$ & $186.78^{\mathrm{c}}$ & $185.94^{\mathrm{c}}$ & $191.94^{\mathrm{b}}$ & $193.91^{\mathrm{b}}$ & 3.23 & $<0.001$ \\
Relative economic efficiency & $1^{\mathrm{a}}$ & $0.56^{\mathrm{e}}$ & $0.68^{\mathrm{d}}$ & $0.72^{\mathrm{c}}$ & $0.71^{\mathrm{c}}$ & $0.73^{\mathrm{b}}$ & $0.75^{\mathrm{b}}$ & 0.01 & $<0.001$ \\
\hline
\end{tabular}

SR, Saudi riyal

TNC, thermoneutral control, HSC, heat stress control; basal diet supplemented with: $1 \%$ Cumin and $1 \%$ turmeric powder (T1); $1.5 \mathrm{~g} / \mathrm{kg}$ potassium chloride and $2 \mathrm{~g} / \mathrm{kg}$ sodium bicarbonate (T2) ; $15000 \mathrm{IU}$ vitamin A and $1000 \mathrm{ppm}$ propolis (T3); $500 \mathrm{ppm}$ vitamin C and $1200 \mathrm{ppb}$ chromium (T4); $1200 \mathrm{ppm}$ betaine and $500 \mathrm{ppm}$ Vitamin E (T5).

*Total cost include (chick price, light, electricity, workers, vaccinations and bedding) 


\section{Discussion}

The current study confirmed the detrimental impacts of heat stress on broilers performance, carcass traits, blood metabolites, antioxidant capabilities and economic efficiency. The harmful effects of heat stress on growth performance indices detected in the current experiment were consistent with previous studies (8, $10,11)$. Heat stress reduces feed intake as an adaptation defense mechanism started by birds to reduce metabolic heat production (20). Heat stress increases free radical generation and lipid peroxidation, which impair growth performance. The improved broiler performance by the selected additive combination in the current studies are matching the findings of earlier studies $(6,7,8,9,10,11,12)$.

Antioxidant vitamins ( $\mathrm{C}$ and $\mathrm{E}$ ) had a beneficial effect in relieving heat stress in broilers through their antioxidant effects (21). Betaine is crucial to be supplied during heat stress, as poultry cannot synthesizes sufficient amount and poultry, feed considers as a poor source (22). This mixture vitamin $\mathrm{E}$ and betaine (Bet with VE) resulted in complete reduction of the negative effect of chronic heat stress (CHS) on broiler performance. The synergetic effect of Bet and vitamin E may reveal the different mode of action of both. The supplementation of betaine and vitamin $\mathrm{E}$ elicit the best significant effect on growth performance and this finding could have important implications in poultry production in subtopic and tropical regions. The potential effect of betaine represented by improving the digestibility of specific nutrients as energy and protein through enhancing the structural and functional characteristics of intestinal epithalia (23). Moreover, dietary supplementation of betaine and vitamin $\mathrm{E}$ combination provides a more potent antioxidant effect, and spares essential amino acids like choline and methionine $(12,23)$. A positive effect was detected between the dietary combination vitamin $\mathrm{C}$ and $\mathrm{Cr}$ as evidenced by their potent antioxidant property against oxidative stress in the current study and confirm the finding of previous studies $(5,24,25)$. There are several explanation for this result, vitamin $\mathrm{C}$ and chromium supplementation increased serum Vit $\mathrm{C}, \mathrm{Cr}$, Vit $\mathrm{E}, \mathrm{Fe}, \mathrm{Zn}, \mathrm{Mn}$ and improved nutrient digestibility in laying hens under cold stress (24). The rate of ascorbic acid uptake into the cells was decreased during heat stress because of the decrease in insulin level and hyperglycemia (25). Chromium indirectly increases the intracellular availability of Vit $\mathrm{C}$ by intensifying the action of insulin (24). The positive impact of the combination of vitamin A and propolis could be due to the role played by vitamin A as an effective radical-trapping antioxidant (26). Heat stress reduce the conversion of carotene to vitamin $\mathrm{A}$ and the concentration of vitamin A decreases during stress conditions so much vitamin A needed during heat stress (26).

The observed beneficial effects of cinnamon and turmeric in the current study could be attributed to their stimulation of appetite, feed intake, digestive enzyme secretions, immune response and the antioxidant actions (27). Increased growth performance and carcass traits by $\mathrm{KCl}$ supplementation could be ascribed to decreased body temperature by more water ingestion after electrolyte supplementation that caused divert more energy toward BW gain. In accordance with the present results, previous studies have demonstrated that, the addition of $\mathrm{KCl}$ and $\mathrm{NaHCO} 3$ during heat stress, at levels of $1.5 \%$ and $0.5 \%$ respectively, improved final weight, feed efficiency and improved $(\mathrm{P}<0.05)$ serum potassium and bicarbonate level through providing of potassium and bicarbonate ions (2).

It has been established that heat stress alter the carcass composition of birds through increasing fat deposition and reducing body protein content (6). The improved carcass characteristics due to the dietary additive in the current study are in line with the finding of previous studies $(6,28,29)$ who reported that supplementation of propolis, ascorbic acid, chromium, and turmeric significantly increased the dressing percentage and improved crass characteristics in chicken reared under heat stress. The increase in dressing percentage in bird receiving vitamin $\mathrm{E}$ and Bet may be due to the osmotic effects of Bet, which increases water re- 
tention and improving the digestibility of energy and protein through enhancing the structure and function of intestinal epithalia and sparing essential amino acids (23). The present findings seem to be consistent with other researches which found that dietary inclusion of vitamin $\mathrm{C}(5,24)$, or $\mathrm{Cr}(24)$ improved all carcass characteristics in broilers. Another study illustrated that $\mathrm{Cr}$ supplementation increased carcass yield and decreased abdominal fat in heat stressed chickens (28).

The increase in glucose concentration in the current study could be ascribed to the increase in glucocorticoids that can result from heat stress as previously explained by (3). Glucocorticoids stimulate gluconeogenesis from muscle tissue proteins. Heat stress increased the plasma level of glucose and cholesterol and decreased total protein levels (30). Both Ascorbic acid and chromium supplementation enhance the utilization of corticosteroids released during stress (24), thus playing a crucial role in response to stress. Vitamin C mitigates the negative effects of stress related depression in poultry performance through reducing synthesis and secretion of corticosteroids (26). The increase in blood lipids under heat stress caused by compensation of energy needed due to the reduction in feed intake through lipolysis of body lipid which resulting in increasing the blood cholesterol and triglyceride levels (30).

The improved in blood oxidant and antioxidant biomarkers caused by dietary additives was in line with the results of previous studies $(4,7,10,21)$. These studies reported that dietary supplementation of chromium, betaine, vitamin E, C, betaine and propolis significantly improved primary and secondary immune response $(\mathrm{P}<0.01)$, and improved $\mathrm{H} / \mathrm{L}$ ratio $(\mathrm{P}<0.05)$. This finding supports previous research of Niu et al. (4) dietary supplementation of Vitamin improved performance and immune competence of broilers under HS.

The improvement in economic efficiency in all treated groups after dietary supplementation of different additive combinations may be attributed to the ability of these additives to increase broiler performance, feed efficiency and their ability to stimulate bird immunity and to reduce mortality rate. This result match those observed in earlier studies $(7,31)$.

\section{Conclusion}

Based on the obtained results, it could be concluded that dietary supplementation of broiler under chronic heat stress with selected additive combinations improved the growth performance, carcass traits, concentrations of serum antioxidant enzyme biomarkers and economic efficiency. From the tested dietary additive combinations, the use of betaine and vitamin $\mathrm{E}$ or chromium and vitamin $\mathrm{C}$ together gave the best results in terms of improved growth performance, feed efficiency, immune response, antioxidant status and profitability of broilers under chronic heat stress. From the findings of the current study, it could be recommend the use of dietary either betaine and vitamin $\mathrm{E}$ or chromium or vitamin $\mathrm{C}$ combinations as a good management practice for mitigating heat stress related depression in the performance of broiler chickens.

\section{Conflict of interest}

The authors declare that they have no conflict of interest

\section{Acknowledgments}

The authors would like to thank the Deanship of Scientific Research, King Faisal University, Al-Ahsa, Saudi Arabia, for financial support of this study (Research Project No. 170007).

\section{References}

1. Mitchell MA, Kettlewell PJ. Physiological stress and welfare of broiler chickens in transit: solutions not problems! Poultry science. 1998; 77(12): 1803-14.

2. Naseem MT, Naseem S, Younus M, Iqbal Ch Z, Ghafoor G, Aslam A, Akhter, S. Effect of potassium chloride and sodium bicarbonate supplementation on thermos-tolerance of broilers exposed to heat stress. International Journal of Poultry Science 2005; 4 (11): 891-5.

3. Quinteiro-Filho WM, Rodrigues MV, Ribeiro A, Ferraz-de-Paula V, Pinheiro ML, Sa LR, Ferreira AJ, Palermo-Neto J. Acute heat stress impairs performance parameters and induces mild intestinal enteritis in broiler chickens: Role of acute 
hypothalamic-pituitary-adrenal axis activation. Journal of Animal Science 2012; 90(6):1986-94.

4. Niu ZY, Wei FX, Liu FZ, Qin XG, Min YN, Gao YP. Dietary vitamin A can improve immune function in heat-stressed broilers. Animal 2009; 3 (10):1442-8.

5. Sahin K, Onderci M, Sahin N, Gursu MF, Kucuk O. Dietary vitamin C and folic acid supplementation ameliorates the detrimental effects of heat stress in Japanese quail. The Journal of Nutrition 2003 ; 133(6): 1882-6.

6. Huang Y, Yang J, Xiao F, Lloyd K, Lin X. Effects of supplemental chromium source and concentration on growth performance, carcass traits, and meat quality of broilers under heat stress conditions. Biological Trace Element Research 2016; 170(1):216-23.

7. Hossain MM, Howlader AJ, Islam MN, Beg MA. Evaluation of locally available herbs and spices on physical, biochemical and economical parameters on broiler production. International Journal of Plant, Animal and Environmental Sciences. 2014; 4 (1) :317-23.

8. Yoo J, Yi YJ, Koo B, Jung S, Yoon JU, Kang HB, Lee DH, Heo JM. Growth performance, intestinal morphology, and meat quality in relation to alpha-lipoic acid associated with vitamin $\mathrm{C}$ and $\mathrm{E}$ in broiler chickens under tropical conditions. Revista Brasileira de Zootecnia 2016; 45(3): 113-20.

9. Guil-Guerrero JL, Ramos L, Paredes JZ, Carlosama-Yépez M, Moreno C, Ruales P. Effects of turmeric rhizome powder and curcumin in poultry production. A review. J. Anim. Feed Sci. 2017; 26(4):293-302.

10. Mahmoud UT, Amen OA, Applegate TJ, Cheng HW. Brazilian propolis effects on growth, productivity performance, gut characteristics and physiological changes in broiler chickens. Int. J. Poult. Sci. 2017; 16:169-79.

11. Chegini S, Kiani A, Rokni H. Alleviation of thermal and overcrowding stress in finishing broilers by dietary propolis supplementation. Italian Journal of Animal Science 2018; 17(2):377-85.

12. Egbuniwe IC, Ayo JO, Kawu MU, Mohammed A. Ameliorative effects of betaine and ascorbic acid on erythrocyte osmotic fragility and malondialdehyde concentrations in broiler chickens during the hot-dry season. Journal of Applied Animal Research 2018; 46(1):380-5.

13. NRC. "National Research Council" Nutrient requirements of poultry. 9th. Rev. (Edn.). National Academy Press, Washington, DC.,
14. AOAC. 1995. Official methods of analysis 16th Ed. Association of Official Analytical Chemists. Washington DC, USA.

15. Gross WB, Siegel HS. Evaluation of the heterophil/lymphocyte ratio as a measure of stress in chickens. Avian Diseases 1983; 27:972-9.

16. Wealleans AL, Li W, Romero LF, Mathis G, Lumpkins B. Performance and cost-benefit improvements following supplementation with a combination of direct-fed microbials and enzymes to broiler chickens raised with or without ionophores. Journal of Applied Poultry Research 2017; 27(1):23-32.

17. Zeweil HS. Evaluation of substituting nigella seed meal for soybean meal on the performance of growing and laying Japanese quails. Egyptian Poultry Science 1996; 16: 451-77.

18. SPSS, Statistical Packages for the Social Sciences. Statistical software for windows version 19.0, Microsoft, IBM Corp. Released 2010. IBM Chicago, IL., USA.2010.

19. Duncan DB. Multiple range tests for correlated and heteroscedastic means. Biometrics 1957; 13(2):164-76.

20. Sahin K, Sahin N, Kucuk O, Hayirli A, Prasad AS. Role of dietary zinc in heat-stressed poultry: A review. Poultry science 2009; 88(10): 217683.

21. Attia YA, Al-Harthi MA, El-Shafey AS, Rehab YA, Kim WK. Enhancing tolerance of broiler chickens to heat stress by supplementation with vitamin $\mathrm{E}$, vitamin $\mathrm{C}$ and/or probiotics. Annals of Animal Science 2017; 17(4):1155-69.

22. Attia YA, Hassan RA, Qota EM. Recovery from adverse effects of heat stress on slow-growing chicks in the tropics 1: Effect of ascorbic acid and different levels of betaine. Tropical animal health and production 2009; 41(5):807-18.

23. Sakomura NK, Barbosa NA, da Silva EP, Longo FA, Kawauchi IM, Fernandes JB. Effect of betaine supplementation in diets for broiler chickens on thermoneutral environment. Revista Brasileira de Zootecnia 2013; 8(2):336-41.

24. Sahin K, Sahin N, Yaralioglu S, Onderci M. Protective role of supplemental vitamin E and selenium on lipid peroxidation, vitamin $\mathrm{E}$, vitamin $\mathrm{A}$, and some mineral concentrations of Japanese quails reared under heat stress. Biological Trace Element Research 2002; 85 (1):59-70.

25. Perai AH, Kermanshahi H, Moghaddam $\mathrm{HN}$, Zarban A. Effects of chromium and chromium+ vitamin $\mathrm{C}$ combination on metabolic, oxidaUSA.1994. 
tive, and fear responses of broilers transported under summer conditions. International journal of biometeorology 2015; 59 (4):453-62.

26. McDowell LR. Comparative aspects to human nutrition. Vitamin A and E. Vitamins in Animal Nutrition. Academic Press, London. 1989:93131.

27. Karami M, Alimon AR, Sazili AQ, Goh YM, Ivan M. Effects of dietary antioxidants on the quality, fatty acid profile, and lipid oxidation of longissimus muscle in Kacang goat with aging time. Meat Science 2011; 88(1):102-8.

28. Toghyani M, Toghyani M, Shivazad M, Gheisari A, Bahadoran R. Chromium supplementation can alleviate the negative effects of heat stress on growth performance, carcass traits, and meat lipid oxidation of broiler chicks without any adverse impacts on blood constituents. Biological Trace Element Research 2012; 146(2):171-80.
29. Wang D, Huang H, Zhou L, Li W, Zhou H, Hou G, Liu J, Hu L. Effects of dietary supplementation with turmeric rhizome extract on growth performance, carcass characteristics, antioxidant capability, and meat quality of Wenchang broiler chickens. Italian Journal of Animal Science 2015; 14(3):3870.

30. Rashidi AA, Ivari YG, Khatibjoo A, Vakili R. Effects of dietary fat, vitamin $\mathrm{E}$ and zinc on immune response and blood parameters of broiler reared under heat stress. Research Journal of Poultry Science 2010; 3 (2):32-8.

31. Chand N, Naz S, Maris H, Khan RU, Khan $\mathrm{S}$, Qureshi MS. Effect of betaine supplementation on the performance and immune response of heat stressed broilers. Pakistan Journal of Zoology 2017; 49(5): 1857-62. 